\title{
Tackling Regional Climate Change Impacts and Food Security Issues: A Critical Analysis across ASEAN, PIF, and SAARC
}

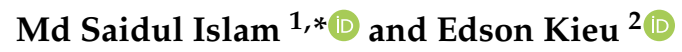 \\ 1 Division of Sociology, Nanyang Technological University Singapore, 48 Nanyang Drive, \\ Singapore 637332, Singapore \\ 2 Strategic Management and Organization, Lee Kong Chian School of Business, Singapore Management \\ University, 50 Stamford Road, Singapore 178899, Singapore; edson.kieu.2016@pbs.smu.edu.sg \\ * Correspondence: msaidul@ntu.edu.sg
}

Received: 16 December 2019; Accepted: 21 January 2020; Published: 24 January 2020

\begin{abstract}
Climate change and food security issues are multi-faceted and transcend across national boundaries. Therefore, this paper begins with the premise that regional organizations are optimally positioned to address climate change and food security issues while actively engaging global partners to slow down or reverse current trajectories. However, the potential of regional organizations to play a central role in mitigating these vital concerns has not been realized. In this paper, we focus on three regional organizations - the Association of Southeast Asian Nations (ASEAN), the Pacific Islands Forum (PIF), and the South Asian Association for Regional Cooperation (SAARC) and set out to investigate the multifaceted obstacles that impede regional organizations' ability to effectively cope with these problems. We qualitatively review the efficacy of policies and examine the connections between politico-economic processes that affect the development, cooperation, and execution of regional policies. In doing so, we review regional policies using five key criteria: (i) planning, (ii) implementation, (iii) cooperation, (iv) legal obligation and (v) international contribution. Our findings suggest that regional organizations face fundamental problems in the implementation of extensive policies due to the lack of cooperation and legal obligation between member nation-states that stems from fundamental prioritization of national development agendas over regional cooperation.
\end{abstract}

Keywords: climate change; food security; regional organizations; ASEAN; PIF; SAARC

\section{Introduction}

Climate change is one of the major challenges affecting human societies and ecosystems. Although its likely impacts remain a matter of contention, new evidence has enhanced our understanding of the extent to which climate change affects us and our environment [1]. Many decision-makers face an uphill task in formulating effective policies to mitigate the threats of climate change, due to its broad scope across many social and environmental spheres. Precautionary actions and policies have been undertaken by many governmental bodies at the international, regional, and national levels, despite gaps in scientific knowledge and uncertainty about effective measures to curtail and mitigate the multifaceted threats [2]. Nonetheless, almost three decades have passed since climate change became a political issue in the 1990s, and the strategies undertaken thus far have failed to produce positive changes or alter the trajectory of climate change [3]. Our knowledge of climate change is slowly revealing the severity of its impact and its contribution to the deteriorating food security situation. The danger to future global food security is a key implication of climate change that fundamentally threatens the survivability and sustainability of all life [4,5]. As such, the central objective of this paper is to highlight the need to re-evaluate the mitigation strategies currently undertaken by governments 
worldwide to assess and address impending climate change threats and reconsider current efforts to deal with climate change and food security. We analyze this across three regional organizations-the Association of Southeast Asian Nations (ASEAN) (ASEAN member states are Indonesia, Thailand, Singapore, Malaysia, Philippines, Vietnam, Cambodia, Myanmar (Burma), Brunei, and Laos), the Pacific Islands Forum (PIF) (PIF member countries include 16 countries namely: Australia, Cook Islands, Federated States of Micronesian, Fiji, Kiribati, Marshall Islands, Nauru, Niue, Palau, Papua New Guinea, Samoa, New Zealand, Solomon Islands, Tonga, Tuvalu, Vanuatu.), and South Asia Association for Regional Cooperation (SAARC) (The seven founding member countries are Bangladesh, Bhutan, India, Maldives, Nepal, Pakistan, and Sri Lanka. Afghanistan joined SAARC in 2007).

This paper posits three salient points. First, climate change's effects will generate a new form of "resource conflict," [1,5,6] leading to an increasingly polarized range of vulnerability between and within regions and nations. This polarization is increasingly evident in the different forms of vulnerability resulting from global climate change, which may be mitigated by national and regional policies [3,7]. Second, climate change requires national and regional actors to take numerous initiatives for the environment, including ensuring food security, protecting the poor by finding economic opportunities, and protecting a "green image" [8]. While there are prospects for regional cooperation and opportunities, competition for power and resources fragments the region, resulting in limited success for numerous initiatives [3,7]. Third, this paper posits that economic growth is necessary but not sufficient to tackle the impacts of climate change and reduce hunger and malnutrition unless it is accompanied by robust public policies and meaningful participation from the poor $[9,10]$. However, food security may be adequately secured by higher incomes and trade, with distribution and/or equality improvements. Because neoliberal logics such as profit and power dominate social and environmental logics like equity and sustainability, levels of consumption remain highly unsustainable, inequitable, and inaccessible to the majority of populations in developing regions [11].

At the policy level, we utilize two methods that dictate policy formulation today: "climate models" and "immediate policy action". Policy-makers utilizing climate models develop appropriate policies based on the assembly of multiple climate models and focus on the possible implications in an attempt to mitigate the risks and advance scientific inquiry. The second method of pursuing immediate policy action involves recognizing overall climate change trends and impacts while providing guidance and responsive policies [12]. Notably, these methods for addressing climate change are not mutually exclusive but are useful for highlighting that policies can be developed despite the contentious nature of information on climate change. Hence, both forms of policies are used to examine regional initiatives.

At the regional level, this paper examines five main ways that regional organizations are vital for the support of food security and for dealing with climate change. The five factors (details in the section below), provide the lens to explore the ability of regional initiatives to address emerging problems [13]. These assertions and critiques in the first two tiers enable an understanding across regions that could facilitate understanding of future policy development and execution, eliciting cross-regional understandings. Information and data for our analysis were retrieved through an archival study. Print sources and webpages were used, including books, government policy documents, technical papers, working papers, journal articles, brochures, and notes. Complementing these sources, regional and country-specific data were collected from websites maintained by government agencies; research, industry, and business organizations; and food- and climate-related institutions. The data were actively cross-examined to gain insights and knowledge about various initiatives that have been undertaken.

Apart from posturing declarations and reactive policies, more substantive proactive initiatives can be undertaken to address impending problems and challenges, particularly at the regional level (The regional level in this paper refers to any policy or initiative that involves a regional or international organization along with two or more nations in an effort to mitigate climate change and food security risks. While the focus is on regional organizations such as ASEAN, PIF, and SAARC, the paper does not specifically exclude other initiatives and collaborations beyond regional organizations). Nonetheless, this paper is not merely a warning; rather, it contributes to the literature on regional management in 
dealing effectively with climate change. By comparing regional policies and initiatives, this paper enhances knowledge of social systems and regional organizations' efforts to deal with climate change and food security issues by highlighting the obstacles to effective policies. Through a closer examination of three regional organizations, ASEAN, PIF, SAARC, this paper highlights systemic weaknesses and suggests further policy reviews to enhance regional cooperation on matters related to climate change and food security.

\section{Conceptual Framework}

\subsection{Multi-Dimensionality of Climate Change and Food Security}

Food security is a universal concept and is a central concern for humanity. However, the concept of food security needs to be constantly revisited, revised, and redefined as societies develop and mature. During the 1996 World Food Summit, the Food and Agriculture Organization of the United Nations (FAO) stated: "food security exists when all people, at all times, have physical and economic access to sufficient, safe and nutritious food that meets their dietary needs and food preferences for an active and healthy life" [14]. The FAO extends this definition with four main dimensions of food, utilization, and stability—as seen in Figure 1 [15].

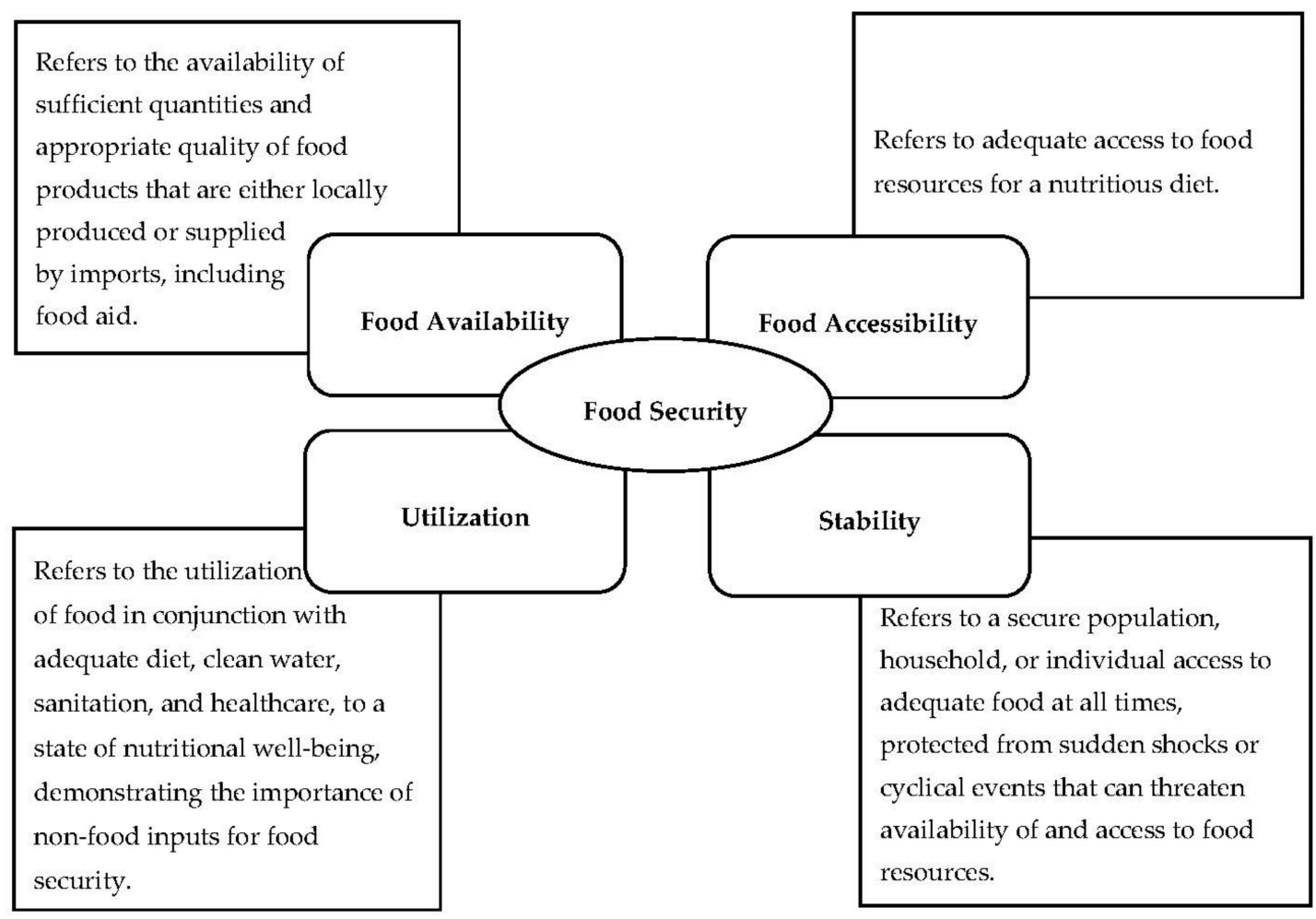

Figure 1. Food and Agriculture Organization of the UN (FAO) Four Dimensions of Food Security Defined.

One reason it is urgent to address climate change is the potentially devastating impact on food security worldwide $[4,16]$. Declining food production and yields from agriculture, aquaculture, and fisheries are the likely results of climate change [17]. Food security has gained increasing prominence over the last few decades, due to projected climate change impacts based on evidence of future and current greenhouse emissions. Information provided by the Intergovernmental Panel on Climate Change (IPCC) suggests that temperatures will rise between 1.1 to 6.4 degrees Celsius by 2100 , based on various scenarios. The IPCC (2007) report highlights that these estimates are based on a hierarchy of models that includes a simple climate model, Earth System Models of Intermediate Complexity, and numerous Atmosphere-Ocean General Circulation Models (AOGCMs) [18]. There are 
two main factors driving detrimental impacts on agricultural productivity: increases in temperatures, and changes in precipitation patterns [19-21]. Changing weather patterns can bring about lowered food and agricultural production, as temperature changes indirectly affect habitat structure, food supply, and resource availability [22-24]. One key dimension of climate change is the projected increase in sea levels, which will cause inundation of agricultural lands. In terms of future food security, higher temperatures will have three types of impact: (i) continuous impacts: changes in agricultural yield due to temperature increases, shifting season lengths, and increased salinity in coastal areas; (ii) discontinuous impacts: increases in harvest failures because of extreme weather patterns and climate-related events like pests and disease outbreaks; (iii) permanent impacts: the irreversible loss of land because of inundation as a result of rising sea levels [12]. Similarly, marine ecosystems are endangered by environmental variables of climate change, such as increases in water temperatures and salinity, disrupting ecosystems and complex food chains [25]. Plankton activity, a vital link in marine ecosystems, will also be affected and may lead to a decline in fisheries' productivity [26,27].

Climate change also impacts natural and human systems such as food production and market commodity chains, with implications for food availability and accessibility across regions. It is also a dialectical phenomenon brought about by greenhouse gas emissions from human activities, reflecting demographic, socio-economic, industrial, and technological developments. The dynamics of climate change and food security are multi-dimensional, and therefore policymakers face tremendous difficulties in evaluating and mitigating the associated threats. The six main trends impacting global food security are shown in Table 1.

Table 1. Trends that Affect Global Food Security.

\begin{tabular}{|c|c|c|c|}
\hline & Factor & Outl & ined Processes \\
\hline 1. & Demographic trends. & (i) & Global demographic trends are increasing along with urban population growth. \\
\hline 2. & $\begin{array}{l}\text { Transformation of } \\
\text { agriculture. }\end{array}$ & $\begin{array}{l}\text { (i) } \\
\text { (ii) } \\
\text { (iii) } \\
\text { (iv) }\end{array}$ & $\begin{array}{l}\text { The agricultural sector's share in GDP is declining. } \\
\text { The proportion of the population working in the agricultural sector is declining. } \\
\text { Farm sizes are decreasing as a result of population growth and } \\
\text { inheritance-based fragmentation. } \\
\text { Agricultural performance is declining due to lowered productivity. }\end{array}$ \\
\hline 3. & $\begin{array}{l}\text { Degradation of natural } \\
\text { resources vital for food } \\
\text { production. }\end{array}$ & $\begin{array}{l}\text { (i) } \\
\text { (ii) } \\
\text { (iii) }\end{array}$ & $\begin{array}{l}\text { Land and water resources are over-exploited. } \\
\text { Arable land size is declining due to a multitude of problems such as water and } \\
\text { wind erosion, desertification and drought, and chemical deterioration. } \\
\text { Climate change results in variable temperatures and precipitation patterns and } \\
\text { increases the magnitude and frequency of extreme weather events. }\end{array}$ \\
\hline 4. & $\begin{array}{l}\text { Rise and volatility of } \\
\text { food prices. }\end{array}$ & (i) & $\begin{array}{l}\text { Prices of almost all types of food have been increasing, including basic } \\
\text { food necessities. } \\
\text { Observed trends of food price volatility have been erratic in the past few years. }\end{array}$ \\
\hline 5. & $\begin{array}{l}\text { Energy security and } \\
\text { impact of biofuels. }\end{array}$ & (i) & $\begin{array}{l}\text { Price increases of food are closely linked to the rising costs of fuel and its direct } \\
\text { impact on the cost of fertilizers, shipping, and transportation. } \\
\text { The expansion of biofuel production and its competition with food crops for land } \\
\text { and other resources is an additional constraint on agricultural production. }\end{array}$ \\
\hline 6. & $\begin{array}{l}\text { Global commodity } \\
\text { supply chain. }\end{array}$ & (ii) & $\begin{array}{l}\text { The transformation of the supply chain has brought about shifts in the way food } \\
\text { is produced, processed, packaged, transported, and distributed. Supply chains } \\
\text { are increasingly owned by large transnational corporations, which has affected } \\
\text { small-scale farmers. } \\
\text { Although consumers may gain from the aforementioned transformations in } \\
\text { terms of improved quality and access to food, the phenomenon has made them } \\
\text { more vulnerable to global commodity fluctuations. }\end{array}$ \\
\hline
\end{tabular}


Deep concerns over food security and climate change have been growing among many governments and organizations. The perils of climate change and its corresponding implication on food production does not respect regional and national boundaries, populations, communities that compounds present inequities. To attain universal food security, every population or individual should have stable access to adequate food at all times and not be at risk of losing access to food due to sudden shocks such as natural and economic disasters or cyclical events and seasonal shortages [15]. While it may seem like a modest goal, the complex nature of these issues is related to the multi-sectoral spectrum of climate change and associated impacts that involve macro systems and sectors like the economy, environment, energy, development, agriculture, fisheries, livestock farming, and forestry. Additionally, the constraints resulting from climate change are compounded by subsequent increasing demands for food, energy, land, and water resources, which could lead to resource-related conflicts that threaten global survival and security. Hence, people and populations need to be protected from unexpected crises and catastrophes that leave them unable to cope with basic food necessities [29].

The conceptual underpinnings of climate change and food security, while separate, are closely intertwined. It is worth highlighting the differences between these concepts and their interrelationship (see Figure 2). First, climate change does not only impact food security, it also affects numerous other sectors. Second, food security is not merely threatened by climate change, but includes a variety of other human and environmental factors. However, because climate change impacts the environment in multiple ways, it is hard to ascertain the direct effects of climate change on food security. In short, although climate change may not seem to be a direct influence on food security, addressing climate change may nonetheless help to create a state where food security is not a primary concern particularly for vulnerable populations.

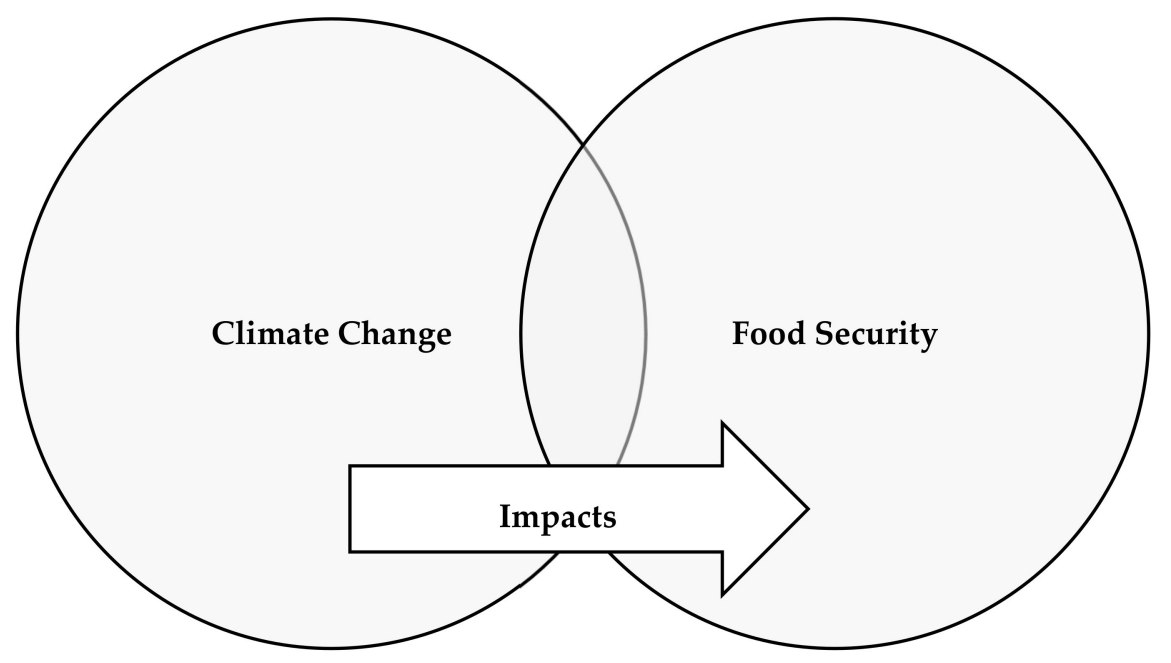

Figure 2. Interrelations between Climate Change and Food Security.

This paper focuses on regional initiatives that targets the potential problems that arise from the impact of climate change on food security. The arrow in Figure 2 indicates that tackling climate-change-related matters will indirectly alleviate impacts and risks that threaten food security. However, implications and impacts from climate change have been a source of controversy due to the nature of elusive and inconclusive projections.

\subsection{Functional Roles of Regional Organizations and Policy Initiatives}

This paper focuses on the intra-regional environmental politics at the regional level as opposed to an account of anthropocentric activities that affect the natural environment. Due to the global nature of climate change and global food chains, as seen in Table 1, this paper posits that regional organizations 
are key to effectively addressing current and future impacts. Regional initiatives to address food security are vital for five main reasons [Table 2].

Table 2. Critical Functions of Regional Organizations.

\begin{tabular}{|c|c|c|}
\hline & $\begin{array}{l}\text { Role of Regional } \\
\text { Organizations }\end{array}$ & Critical Functions \\
\hline 1. & Market regulation & $\begin{array}{l}\text { Regional initiatives can regulate regional markets effectively by implementing } \\
\text { controls over volatile global food markets. Such controls will ensure the stability } \\
\text { and dependability of imports and exports of vital food resources. }\end{array}$ \\
\hline 2. & Internal supply chain & $\begin{array}{l}\text { Regional initiatives can enhance food security internally by supplying essential } \\
\text { food resources that are relevant to regional needs. Internal supply chains can act } \\
\text { as a buffer from price volatility and the monopoly of major multinational } \\
\text { corporations over global food supply and the commodity market. }\end{array}$ \\
\hline 3. & $\begin{array}{l}\text { Cooperation and } \\
\text { good governance }\end{array}$ & $\begin{array}{l}\text { It is vital to encourage cooperation between stakeholders and ensure good } \\
\text { security sector governance. Cooperation means that decision-making is objective } \\
\text { and responsive to public needs and demands and provides a multi-level concept } \\
\text { of security while promoting the transfer and sharing of knowledge. }\end{array}$ \\
\hline 4. & $\begin{array}{l}\text { Need-based food } \\
\text { production }\end{array}$ & $\begin{array}{l}\text { It is necessary to increase food security by directing and managing food } \\
\text { production in line with food consumption patterns, which could account for } \\
\text { regional socio-economic shifts that are not bounded within nations. National } \\
\text { development agendas that focus on industrialism otherwise lead to declining } \\
\text { investments in agriculture, thus making nations reliant on food imports and } \\
\text { subject to market fluctuations and possible shortfalls. }\end{array}$ \\
\hline 5. & $\begin{array}{l}\text { Protecting the } \\
\text { marginal } \\
\text { communities }\end{array}$ & $\begin{array}{l}\text { Regional initiatives are vital to ensure food security for marginalized } \\
\text { communities, which are often minorities that have been displaced and } \\
\text { persecuted by their own governments. Hence, regional involvement could } \\
\text { provide the necessary blanket of security for marginalized populations facing } \\
\text { internal persecution. }\end{array}$ \\
\hline
\end{tabular}

The following sections will show that regional organizations such as ASEAN, PIF, and SAARC have begun adopting a precautionary stance, undertaken steps to mitigate impacts, but have yet to develop a system to address regional patterns of production and consumption. Many regional initiatives focus on mitigating threats to the food industry from climate change but neglects developinga systemic process to integrate regional support and supply, to enhance food security for the region. ASEAN, PIF, and SAARC have over the past decades undertook mitigation and preventive measures for managing the risks associated with climate change in relation to food security. The following sections elucidate the existing agenda for regional cooperation concerning climate change and food security.

\section{Regional Stance and Initiatives}

\subsection{ASEAN Food Security and Climate Change Frameworks and Initiatives}

ASEAN is keenly aware of the region's vulnerability to climate change. ASEAN joint statements on climate change have involved ASEAN Heads of State and various governments, who seek to address climate change and the global community. The ASEAN joint statements released in 2007, 2009, 2010, 2011, and 2014 outlined an "aspiration towards a global solution to the challenge of climate change and their resolve to achieve an ASEAN community resilient to climate change through national and regional actions" [30]. The ASEAN community has three pillars, as named in the Declaration of the ASEAN Concord II in 2003: the political and security community, the economic community, and the socio-cultural community. As part of the ASEAN community, the ASEAN Socio-Cultural Community (ASCC) oversees the ASEAN Climate Change Initiative (ACCI), a comprehensive, cross-sectoral platform for coordination and cooperation, designed to respond specifically to climate change and its impacts. The ACCI aims to provide a platform for sectors such as energy, forestry, agriculture, and disaster management to address climate change impacts. Second, as part of ASEAN's endeavors to deal with climate change, the ASEAN Action Plan on Joint Response to Climate Change highlights 
several key areas that ASEAN will engage in by leveraging the ACCI. Apart from climate change, ASEAN has also developed mitigation strategies to address food security. The initial agreement for ASEAN cooperation on food security is guided by the 1979 Agreement on the ASEAN Food Security Reserve, the Vientiane Action Programme (2004-2010), the ASEAN Economic Community Blueprint, and most recently the ASCC Blueprint. Because of the volatility of food prices, distribution, and access, ASEAN nations began discussing future and long-term strategies for food security in the region. Concrete plans were discussed in the Special Senior Officials Meeting during the 29th Meeting of the ASEAN Ministers on Agriculture and Forestry (Special SOM-29th AMAF) in August 2008, which were based on the concept note of the ASEAN Integrated Food Security (AIFS) Framework [29]. A work plan was also solidified in the Strategic Plan of Action on Food Security for the ASEAN Region (SPA-FS), for consideration and endorsement at the AMAF meeting during the 2008 ASEAN Summit [30].

The SPA-FS serves as a support to the AIFS framework. The AIFS and SPA-FS are an attempt to systematize an approach to food security. The AIFS framework is a regional umbrella for food-security-related initiatives, including bioenergy and climate change, and the goal is to ensure long-term food security and improve the livelihoods of farmers in the ASEAN region. As an extension of AIFS, the Agriculture, Fisheries and Forestry towards Food Security provide inputs to the ACCI for better cross-platform understanding and interactions between climate change and food security with an emphasis on cooperating on, coordinating, and implementing adaptation and mitigation strategies. Its main goal is "to contribute to food security through sustainable and efficient use of land and water resources by minimizing the impacts of and the contributions to climate change" [31].

There are also two additional supportive mechanisms: the ASEAN Plus Three Emergency Rice Reserve (APTERR) and ASEAN Food Security Information System (AFSIS). APTERR serves as an emergency food reserve for the ASEAN region and three additional members: Japan, China, and South Korea. APTERR was established after the food crisis in 2008, in which export bans and increased import orders led to uncertainty in the rice market. Under APTERR the rice reserve will be available for consumption through a triple-tiered system of commercial contracts, emergency grants, and delivery in times of acute emergency. AIFSIS, in contrast, began operation in 2003 to build future capacity for the systematic collection, analysis, and dissemination of food-related information. AFSIS enables the sharing of human resources and knowledge and technical cooperation for the management of early warning systems and food policy programs. Assessments will enable the region to identify areas where food insecurity is likely to take place [28-33]. These regional initiatives are synergistic and together aim to ensure that ASEAN remains resilient as a regional organization that coordinates cohesive efforts by providing a balance between economic and social development.

\subsection{PIF Food Security and Climate Change Frameworks and Initiatives}

The threat of climate change is well accepted in the Pacific Islands Forum (PIF) region. Its Secretariat has acknowledged that climate is an "immediate and serious threat to sustainable development and poverty eradication" [34]. Many of PIF's member countries will bear a significant disproportion of impacts from climate change with respect to their contribution to global emissions. In 2009, during the Forums Leaders' Communique, the Pacific Leaders issued a call to action on climate change; they claimed that the "very viability of some of our communities" and the "security of our communities and the health of populations are in great jeopardy. And some habitats and island States face obliteration" [35]. The call to action referenced the Niue Declaration on Climate Change during the Pacific Islands Forum's Smaller Island States (SIS) Leaders' Summit, held on August 19, 2008. The Niue Declaration was a watershed in highlighting the seriousness of future climate change impacts on the region and urging the support of the international community. One year on, the Pacific Leaders' call to action similarly urged the international community to create effective global agreements, because it was not on track to achieve the desired outcomes [34,35].

The leaders of PIF's member countries tasked the PIF Secretariat with exploring options to effectively manage international climate change and facilitate the management of resources at the 
national level. The PIF Secretariat engages in multi-tiered, multi-stakeholder initiatives. Apart from engaging member nations, the PIF Secretariat also collaborates with Council of Regional Organizations in the Pacific (CROP) agencies like SPREP and the Secretariat of the Pacific Community (SPC), in addition to the United Nations Development Programme (UNDP), Australian Aid (AusAID), European Union (EU), United States Agency for International Development (USAID), Asian Development Bank (ADB), and the World Bank (WB). Although the PICTs have multiple partnerships addressing climate change and food security, the main coordinating body, the Pacific Islands Framework for Action on Climate Change, was established in 2005. This framework aimed to safeguard Pacific Island communities in building resilient and risk-averse capacities to mitigate the risks associated with climate change. PIF actively engages a range of collaborative efforts for coordinating regional organizations with international partners for development at the national level. The programs foster a multidisciplinary approach by consulting technical and scientific experts and the dissemination of best practices and strategies to boost national development sustainability relative to food security and adaptive capacities for climate change. Programs for the PICTs engage with climate change by information-gathering and developing innovative adaptive mechanisms to mitigate the threats they face. By improving the region's knowledge about climate change, the region will be able to develop Action Plans to communicate between stakeholders, thereby budgeting for and implementing institutional capacity to address regional climate change variability and vulnerability [26-28,34,35].

As in many other regions, food security in the Pacific is complex and multifaceted. Attaining food security requires a coordinated multisector approach, engaging all stakeholders and building capacity within food production and food distribution networks. As such, the Framework for Action aims to adopt close partnerships to build regulatory cost-effective, efficient frameworks that can operate at the regional level. The Framework for Action on Food Security is a call to action by Pacific Islands leaders issued during the 39th Pacific Islands Forum. The agenda set out by this framework was unanimously accepted by all PIF nations. This framework promotes investments, research and development, capacity-building, and adaptation that can mitigate climate change threats [34]. The implementation of the Framework for Action on Food Security in the Pacific led to the development of the Food Secure Pacific Working Group (FSPWG), which is focused on aligning activities among all participants. The FSPWG facilitates and monitors progress at the regional and national levels across multiple sectors. This will lead to food security implementation plans that use a "whole-of-society" approach featuring good governance and accountability [35]. The second implementing agent of the Framework for Action is Industry Partners for a Food Secure Pacific (IPFSP). The IPSFP comprises food industry partners from Fiji, Samoa, Solomon Islands, Tonga, and Vanuatu [35]. Potential actions have been drafted to address regional goals at the national level. Some of these actions include the strengthening oflegislative frameworks, public-sector monitoring, and private sector compliance, including the involvement of all stakeholders in legislation formulation to facilitate collaboration between private and public sectors for food quality and safety [34]. The planned outcomes are to (i) strengthen policy, (ii) increase the productivity in agriculture and the fisheries, (iii) increase the contribution of oceanic fishery resources to domestic supplies, (iv) enhance food processing capacity while value-adding to agriculture and fish products, and (v) increase the competitiveness of agriculture and fisheries in the domestic and international markets while actively promoting sustainable management of these land and marine resources.

Additionally, PIF nations individually explore project collaborations with international and regional organizations to address food security issues. The PICTs recognize that each nation has its own responsibility to address the risks and effects of climate change as part of its national development. Building these systems and projects can help strengthen these nations' resilience and associated ecological, economic, and social vulnerability. The engagement of multiple stakeholders and integrated sectoral development strategies will help improve long-term capacity-building. 


\subsection{SAARC Food Security and Climate Change Frameworks and Initiatives}

SAARC first began documenting intergovernmental initiatives about the environment as early as 1982, with reports such as "Causes and Consequences of Natural Disasters and the Protection and Preservation of the Environment" and "Greenhouse Effect and its Impact on the Region". Officially, SAARC only began expressing deeper concerns over climate change during the 2007 Fourteenth SAARC Summit in New Delhi. These concerns raised over climate change saw SAARC undertaking initiatives to address the challenges. Follow-ups on climate change were added to the official agenda during the Dhaka Declaration, which translated to initiatives and activities to promote advocacy programs, cooperation for capacity-building, and exchange of best practices, research, and mitigation adaptation measures. From 2009 to 2011, the SAARC Action Plan on climate change was realized, which addressed seven themes and areas for cooperation. During 2009, SAARC member nations also signed the Delhi Statement on Cooperation in Environment, which reaffirms cooperation. In 2010, the Thimphu Statement on Climate Change was outlined to strengthen and facilitate regional cooperation to address the adverse impacts of climate change. In relation to food security, the 1987 SAARC Agreement on Establishing the SAARC Food Security Reserve is the only binding agreement among the member states that addresses food security [36-39].

Back in 1982, the intergovernmental initiative "South Asia Co-operative Environment Programme" engaged in transboundary environmental issues and provided a crucial forum for promoting regional cooperative activities related to the environment. One of its aims was to address climate change by taking relevant actions and solving trans-boundary environmental issues like pollution. While these aims may not seem to be directly related to food security, attempts to address climate change may nonetheless alleviate climate change impacts on food security. In 1992, the SAARC member nations set up a Technical Committee on Environment that aimed to identify measures and recommendations on conservation of natural resources, biological diversity, alternative fuels, greenhouse gas emissions, rising sea levels, increased water salinity, and changes in rainfall patterns. The committee reportedly met numerous times over the last two decades to assess the progress and plans of SAARC to ensure environmental sustainability [36-39].

The SAARC Ministerial Meeting on Climate Change was one of the watershed events for climate change. It was held in Dhaka in 2008 and resulted in the adoption of the "Dhaka Declaration and SAARC Action Plan on Climate Change." The Dhaka Declaration requires member states to build capacity, exchange information, promote advocacy programs and mass awareness of climate change, provide incentives for the reduction of greenhouse gases, and undertake mitigation and adaptation measures for climate change. The SAARC Action Plan on Climate Change also resulted from the same Ministerial Meeting and identified seven thematic areas for cooperation among member states. The SAARC Action Plan on Climate Change themes points to areas that have room for capacity-building: Clean Development Mechanisms projects, informational exchange on climate change impacts, and engaging in international negotiations. Under the SAARC Action Plan, the Technical Committee on Environment and Forestry was created to enhance South-South cooperation on climate change and generate support and action plans on the national and regional levels. One crucial aspect of the SAARC Action Plan is the agricultural focus, which will address the assessment of climate change and adaptive measures in response to it [36-39].

2009 and 2010 saw two additional statements: the Delhi Statement on Cooperation in Environment and the Thimphu Statement on Climate Change. The Delhi Statement on Cooperation in Environment 2009 identifies and reaffirms the commitment of all member states to regional cooperation regarding climate change. The commitment of the SAARC members to the SAARC Action plan is clear, as their commitment was reiterated by the Thimphu Statement on Climate Change, established during the Sixteenth Summit that outlines initiatives at the national and regional levels. The Thimphu Statement also saw the formation of the Inter-Governmental Expert Group on Climate Change (IGEG.CC). The IGEG.CC's role is to monitor, review progress, and make recommendations to the SAARC Environment Ministers that will facilitate the implementation of the Thimphu Statement. To further 
support food security, SAARC members have come together as a region to ensure food security by establishing a food reserve, which will (i) "act as a regional food security reserve for the SAARC Member Countries during normal time food shortages and emergencies"; and (ii) "provide regional support to national food security efforts; foster intercountry partnerships and regional integration, and solve regional food shortages through collective action" [36,39].

Apart from internal initiatives within SAARC member states or by SAARC as a regional organization, South Asian nations engage with international partners for food security. These bilateral and multilateral initiatives connect South Asian nations with global, national, and regional support.

\section{Policy Planning and Initiative Analysis}

We utilize five regional facets [13] to evaluate initiatives and examine climate change in ASEAN, PIF, and SAARC, These facets include: (i) planning, (ii) implementation, (iii) cooperation, (iv) legal obligation and $(\mathrm{v})$ international contribution. Each facet acts as a lens through which we evaluate the overall ability of each regional organization to deal with the challenges of climate change and food security.

\subsection{ASEAN Regional Initiatives}

ASEAN made early attempts to regulate regional markets during the sharp increase in international food prices from 2007 to 2008, which prompted serious concerns over food shortages and their associated socio-economic impacts on ASEAN nations. Hence, it was deemed necessary for ASEAN nations to cooperate and address food security problems while strengthening existing ASEAN initiatives and measures. Various economic impacts on the supply side include the increase of agricultural production costs, such as cost-led increases in fuel oil and fertilizer costs and increased expenses from storing perishable goods, compounded by the decline in agricultural yield. On the demand side, increases in food prices are related to the structural change of global demand for food commodities and varying competition, in addition to market speculation of the biofuels and agricultural sectors [29].

Notably, ASEAN nations have tried to mitigate the impacts of market prices by implementing market controls and economic measures like export restrictions, price controls, price subsidies, and import facilitation. However, as the ASEAN Sustainable Agrifood Systems (2014) report notes, market interventions often result in winners and losers; the need to help protect consumers and assist agricultural producers has led to the AIFS and SPA-FS frameworks. The AIFS and SPA-FS frameworks include six initial strategic thrusts as seen in Figure 3 and an additional three strategic thrusts in Table 3. The mechanisms of both frameworks (APTERR, which attempts to enhance food security by supplying essential food resources, and AFSIS, which attempts to ensure cooperation during food crises) are reactive and weak. Putting APTERR into perspective: the total reserves of 787,000 tons will only be worth two days of regional consumption, which numbers 542,000 tons a day [28]. In addition, the corresponding contribution and commitment of each ASEAN nation is its domestic consumption for a single day. These figures fall short of its regional efforts to provide reserves that could last for one to two weeks of domestic consumption. There is, therefore, a need for ASEAN nations to show greater levels of commitment to APTERR's operational capacity. The critique highlights that the non-utilization of APTERR reserves is related to its inefficient request and delivery procedures [28]. Other issues cited relates to differentiation in nations' capacity to fulfill APTERR responsibilities, issues related to financial sustainability, and trade-offs between food security and storage costs [28]. Second, AFSIS will enable the region to identify areas where food insecurity is likely to take place [28]. Despite acknowledging significant progress in operationalizing AFSIS, it is claimed that the quality and reliability of data remain a concern [28]. Data quality can be improved through the periodic analysis of food supply and demands. Some form of technology-shared across nations with technical capacity could help those without such established methods for data production. Establishing links across stakeholders and improving informational quality and dissemination will help boost AFSIS to greater potential. 


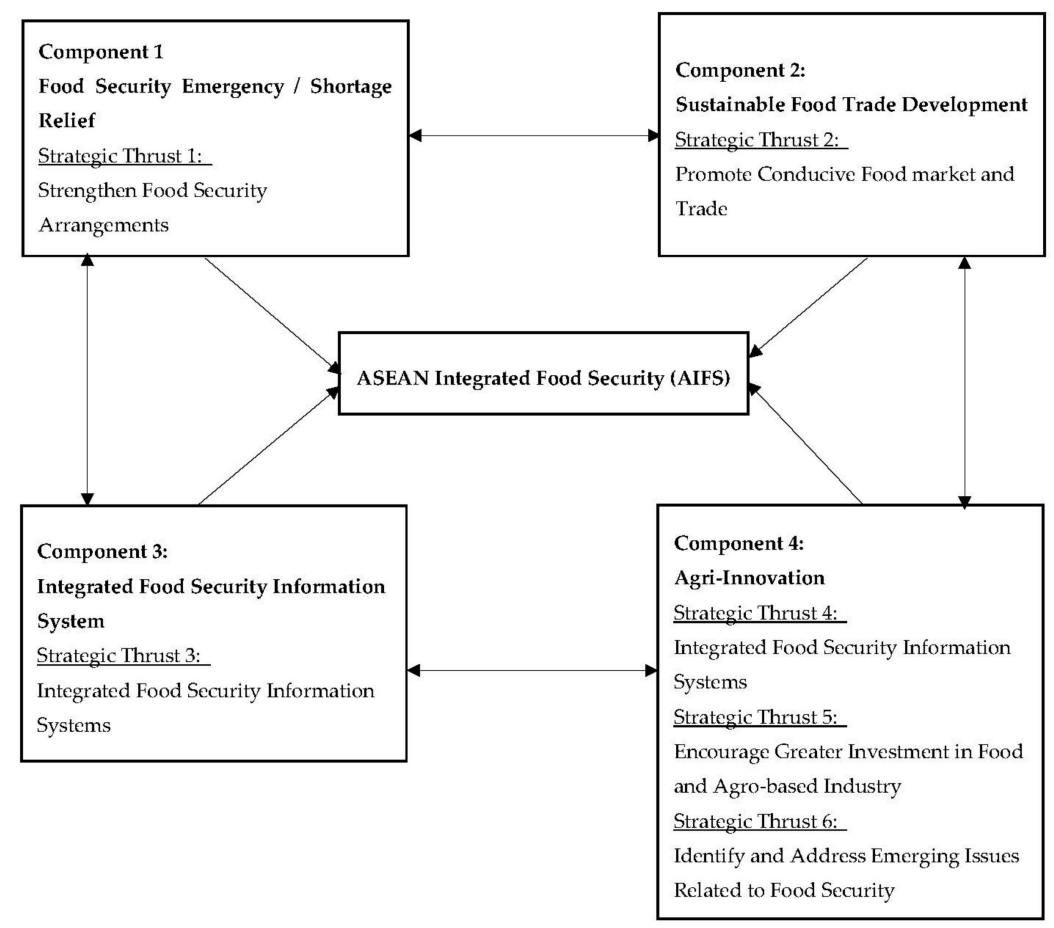

Figure 3. The ASEAN Integrated Food Security (AIFS) Framework and its Components [29,32].

Table 3. Fifth Component "Nutrition-Enhancing Agricultural Development".

\begin{tabular}{ll}
\hline Strategic Thrust 7 & $\begin{array}{l}\text { Utilize nutrition information to support evidence-based food } \\
\text { security and agriculture policies. }\end{array}$ \\
\hline Strategic Thrust 8 & $\begin{array}{l}\text { Identify policies, institutional and governance mechanisms for } \\
\text { nutrition-enhancing agriculture development in ASEAN } \\
\text { Member States. }\end{array}$ \\
\hline Strategic Thrust 9 & $\begin{array}{l}\text { Develop and strengthen nutrition-enhancing food, agriculture } \\
\text { and forestry policies/programs and build capacity for their } \\
\text { implementation, monitoring and evaluation. }\end{array}$ \\
\hline
\end{tabular}

Source: [32].

Other ASEAN initiatives such as ACCI do attempt to manage aspects of climate change and food security. Some key areas highlighted are: (i) Adaptation: sharing information on food security, agricultural management and productivity, water resource sustainability, and ongoing efforts in urban, rural, and coastal areas, in addition to enhancing existing ASEAN climate/meteorological/oceanographical networks. (ii) Mitigation: sharing best practices to mitigate greenhouse gas emissions; promoting a common understanding through workshops on Nationally Appropriate Mitigation Actions (NAMAs) and Measurement, Reporting and Verification (MRV); sharing information on promoting, developing, and enhancing Clean Development Mechanisms (CDM); and exploring implementation of a carbon cap and trade system within the region. (iii) Finance and Investment: promoting common understanding on accessing multilateral funds. (iv) Technology Transfer: facilitating international support for technological transfer to ASEAN, which could aid needs assessment, mitigation, and adaptation; sharing information and experience in science and policy; and developing strategic alliances to promote research and development with private sectors. (v) Capacity Building: facilitating regional and international support in capacity-building for ASEAN and long-term regional cooperation integrating experiences of strengthening adaptive capacities of communities. (vi) Other Matters of Regional Cooperation: encouraging collaboration with other existing regional institutions and promoting better collaboration on climate-change-related issues [33]. However, commitment to the aforementioned pointers has yet to see regional cooperation to manage 
and direct food production and distribution networks with various multi-sector and multi-stakeholder partnerships. In addition, the needs of marginalized and peripheral communities have not been actively addressed in ASEAN's food security framework.

\subsection{PIF Regional Initiatives}

PIF is particularly committed to engaging various stakeholders, including international organizations and the private sector, with a strong focus on improving the region's knowledge and capacity building. To improve food security internally, PIF has attempted to direct and manage food production through engagement with various stakeholders. This effort is clearly seen in programs such as "Coping with Climate Change in the Pacific Island Region," involving the Gesellshaft für Internationale Zusammenarbeit, SPC, and SPREP as developmental partners; "Pacific Adaptation to Climate Change" between the SPREP and UNDP; and "Vegetation and Land Cover Mapping and Improving Food Security for Building Resilience to a Changing Climate in Pacific Island Communities" by the SPC. However, these programs can be critiqued for mainly concentrating on production systems rather than distributive networks, as well as neglect for marginalized communities. A majority of the programs target only clusters of member states and fail to encompass the entire region. PIF does not have plans to manage and supply essential food sources for the entire region but mainly develops community-level mitigation strategies as part of pilot projects. In addition, PIF does not regulate regional markets, nor is there any means to build adaptive capacities to supply the region with essential food resources. Holistically speaking, PIF is still highly reactive to climate change, but it nonetheless furthers its strategies by establishing better knowledge and information for the utilization of climatic models to enhance food security $[40,41]$.

Although the Framework for Action on Food Security does seem to be all-encompassing, with six themes as summarized in Table 4, many implemented programs to date do not operate in conjunction with the six themes and it remains merely a conceptual model thus far.

Table 4. Six Themes to Improve Food Security, the Pacific Islands Forum (PIF) Framework for Action.

\begin{tabular}{|c|c|c|}
\hline Theme & Recognition & Intention \\
\hline Theme 1 & $\begin{array}{l}\text { Leadership and Cooperation-Recognizes that sectors } \\
\text { cannot operate alone. The government needs to rely on } \\
\text { important partners such as the civil society, healthcare, } \\
\text { food industries, trade and donor partners that can help } \\
\text { cooperate and build a more resilient food system. }\end{array}$ & $\begin{array}{l}\text { This theme will rectify the issues with } \\
\text { coordination, communication and resources } \\
\text { as obstacles to food security. }\end{array}$ \\
\hline Theme 2 & $\begin{array}{l}\text { Regulatory frameworks, enforcement, compliance and } \\
\text { public-private sector collaboration-This theme } \\
\text { recognizes the importance of partnerships and } \\
\text { collaboration across public and private spheres, which } \\
\text { will hold the ability to legislate food frameworks, based } \\
\text { on formulation, implementation and enforcement. }\end{array}$ & $\begin{array}{l}\text { Consumers of food produce will be assured of } \\
\text { access to quality food. }\end{array}$ \\
\hline Theme 3 & $\begin{array}{l}\text { Enhanced and sustainable production, processing and } \\
\text { trading of safe and nutritious local food-This theme } \\
\text { understands that food security can be improved with } \\
\text { better availability, access, stability and the sustainability } \\
\text { of local food production. }\end{array}$ & $\begin{array}{l}\text { Ensures that consumers are able to obtain all } \\
\text { vital aspects of food security. }\end{array}$ \\
\hline Theme 4 & $\begin{array}{l}\text { Protect infants and vulnerable groups-This theme } \\
\text { stresses that food security issues should also be paid } \\
\text { attention to the needs of infants and vulnerable groups. }\end{array}$ & Safeguards all social groups including infants. \\
\hline Theme 5 & $\begin{array}{l}\text { Consumer empowerment and mobilizing partners-This } \\
\text { theme recognizes that all sectors and agencies should } \\
\text { provide consumers with information and enable them to } \\
\text { have the ability to make informed decisions about food. }\end{array}$ & $\begin{array}{l}\text { This will enable the promotion of healthy } \\
\text { options and better environmental changes. }\end{array}$ \\
\hline Theme 6 & $\begin{array}{l}\text { Food security information system-This theme } \\
\text { recognizes the need for robust evidenced-based } \\
\text { information about food security. }\end{array}$ & $\begin{array}{l}\text { This will result in a framework that can help } \\
\text { monitor and evaluate progress while aiding } \\
\text { the dissemination of new ideas and initiatives. }\end{array}$ \\
\hline
\end{tabular}


Although it is vulnerable to critique, the PIF Framework for Action on Food Security in the Pacific has brought about a framework that has vast future potential. The "whole society" approach and involvement of food industry partners has been positive, especially as the implementing agent of the Framework for Action is Industry Partners for a Food Secure Pacific (IPFSP). IPSFP comprises food industry partners from Fiji, Samoa, Solomon Islands, Tonga, and Vanuatu [35]. Industry partners have endorsed the goals of the Framework and will pursue the six themes in Table 3. However, over-reliance on developmental partners could jeopardize the sustainability of many of these programs, due to many PIF nations' lack of financial and technical capacities. Due to the varied partnerships of multiple projects undertaken within the region, PIF as a regional forum plays only a facilitative role in drafting agendas for the region and is therefore overly reliant on uptake from partners to support its programs and agenda. Furthermore, PIF requires external funding arrangements for PICTs, which may be a shortcoming in developing a regionally coordinated effort. The reliance on short-term projects and programs may be a major shortcoming, which could be detrimental in the long run due to the lack of resilient mechanisms $[35,40,41]$.

\subsection{SAARC Regional Initiatives}

SAARC acknowledges deep concerns over climate change impacts, and its regional efforts have been rhetorically addressed. However, there are signs of a lack of political will among member states, as regional initiatives have mainly centered on preliminary approaches such as the opening of endorsements, agreements, and cooperative avenues to monitor and share practices regionally. Nevertheless, the seven thematic areas highlighted under the SAARC Action Plan on Climate Change and the scope in which the Technical Committee on Environment engages in shows the vast potential for cooperation among SAARC nations. The themes for environmental cooperation are fully encompassing, addressing crucial aspects of cooperation ranging from policies and action, finances, education and awareness, adaptation measures, management, and capacity building, as shown in Table 5. However, SAARC still lacks engagement with vulnerable populations and local communities, which may be crucial as an adaptive mechanism for effectively dealing with climate change and food security threats. Notwithstanding, the Delhi and Thimphu Declarations have been endorsed over the years as an agreement on and commitment to regional cooperation.

The SAARC has been undeniably quick to speak up about climate change and its impacts, beginning in the 1980s. A crucial forum, the South Asia Cooperative Environment Programme, was formed to engage in transboundary environmental issues and offers a clear affirmation by SAARC member states to endorse thematic areas for cooperation under the SAARC Action Plan on Climate Change.

In direct relation to food security, SAARC members have come together as a region to ensure food security by establishing a food reserve. This will serve to (i) "act as a regional food security reserve for the SAARC Member Countries during normal time food shortages and emergencies"; and (ii) "provide regional support to national food security efforts; foster intercountry partnerships and regional integration, and solve regional food shortages through collective action" [37]. Under this agreement, the SAARC Food Bank will hold in reserve the following food grains (see Table 6). 
Table 5. The Thimphu Statement on Climate Change: Main points.

\begin{tabular}{|c|c|}
\hline & Agenda \\
\hline 1. & $\begin{array}{l}\text { Review the implementation of the Dhaka Declaration and SAARC Action Plan on Climate Change } \\
\text { and ensure its timely implementation. }\end{array}$ \\
\hline 2. & $\begin{array}{l}\text { Agree to establish an Inter-governmental Expert Group on Climate Change to develop clear policy } \\
\text { direction and guidance for regional cooperation as envisaged in the SAARC Plan of Action on } \\
\text { Climate Change. }\end{array}$ \\
\hline 3. & $\begin{array}{l}\text { Direct the Secretary General to commission a study for presentation to the Seventeenth SAARC } \\
\text { Summit on "Climate Risks in the Region: ways to comprehensively address the related social, } \\
\text { economic and environmental challenges." }\end{array}$ \\
\hline 4. & $\begin{array}{l}\text { Undertake advocacy and awareness programs on climate change, among others, to promote the use } \\
\text { of green technology and best practices to promote low-carbon sustainable and inclusive } \\
\text { development of the region. }\end{array}$ \\
\hline 5. & $\begin{array}{l}\text { Commission a study to explore the feasibility of establishing a SAARC mechanism which would } \\
\text { provide capital for projects that promote low-carbon technology and renewable energy; and a } \\
\text { Low-carbon Research and Development Institute in South Asian University. }\end{array}$ \\
\hline 6. & $\begin{array}{l}\text { Incorporate science-based materials in educational curricula to promote better understanding of the } \\
\text { science and adverse effects of climate change. }\end{array}$ \\
\hline 7. & $\begin{array}{l}\text { Plant ten million trees over the next five years }(2010-2015) \text { as part of a regional afforestation and } \\
\text { reforestation campaign, in accordance with national priorities and programmes of Member States. }\end{array}$ \\
\hline 8. & $\begin{array}{l}\text { Evolve national plans, and where appropriate regional projects, on protecting and safeguarding the } \\
\text { archaeological and historical infrastructure of South Asia from the adverse effects of Climate Change. }\end{array}$ \\
\hline 9. & $\begin{array}{l}\text { Establish institutional linkages among national institutions in the region to, among others, facilitate } \\
\text { sharing of knowledge, information and capacity building programmes in climate change } \\
\text { related areas. }\end{array}$ \\
\hline 10. & $\begin{array}{l}\text { Commission a SAARC Inter-governmental Marine Initiative to strengthen the understanding of } \\
\text { shared oceans and water bodies in the region and the critical roles they play in sustainable living to } \\
\text { be supported by the SAARC Coastal Zone Management Center. }\end{array}$ \\
\hline 11. & $\begin{array}{l}\text { Stress the imperative of conservation of bio-diversity and natural resources and monitoring of } \\
\text { mountain ecology covering the mountains in the region. }\end{array}$ \\
\hline 12. & $\begin{array}{l}\text { Commission a SAARC Inter-governmental Mountain Initiative on mountain ecosystems, } \\
\text { particularly glaciers and their contribution to sustainable development and livelihoods to be } \\
\text { supported by SAARC Forestry Center. }\end{array}$ \\
\hline 13. & $\begin{array}{l}\text { Commission a SAARC Inter-governmental Monsoon Initiative on the evolving pattern of monsoons } \\
\text { to assess vulnerability due to climate change to be supported by SAARC Meteorological } \\
\text { Research Center. }\end{array}$ \\
\hline 14. & $\begin{array}{l}\text { Commission a SAARC Inter-governmental Climate-related Disasters Initiative on the integration of } \\
\text { Climate Change Adaptation (CCA) with Disaster Risk Reduction (DRR) to be supported by SAARC } \\
\text { Disaster Management Center. }\end{array}$ \\
\hline 15. & $\begin{array}{l}\text { Complete the ratification process for the SAARC Convention on Cooperation on Environment at } \\
\text { an early date to enable its entry into force. }\end{array}$ \\
\hline 16. & $\begin{array}{l}\text { The Inter-governmental Expert Group on Climate Change shall meet at least twice a year to } \\
\text { periodically monitor and review the implementation of this Statement and make recommendations } \\
\text { to facilitate its implementation and submit its report through the Senior Officials of SAARC to the } \\
\text { SAARC Environment Ministers. }\end{array}$ \\
\hline
\end{tabular}


Table 6. Assessed Shares of Food Grains for the South Asian Association for Regional Cooperation (SAARC) Food Reserve.

\begin{tabular}{llll}
\hline & & & In Metric Tons \\
\hline & Country & $\begin{array}{l}\text { Quantity (Decision of the 1st Meeting in } \\
\text { Colombo, 2008) }\end{array}$ & $\begin{array}{l}\text { Quantity (Decision of the 3rd Meeting in } \\
\text { Kabul, 2009) }\end{array}$ \\
1. & Afghanistan & Data not available & 2840 \\
2. & Bangladesh & 40,000 & 80,000 \\
3. & Bhutan & 180 & 360 \\
4. & India & 153,200 & 306,400 \\
5. & Maldives & 200 & 400 \\
6. Nepal & 4000 & 8000 \\
7. & Pakistan & 40,000 & 80,000 \\
8. Sri Lanka & 4000 & 8000 \\
TOTAL & 241,580 & 486,000 \\
\hline
\end{tabular}

Source: [37].

SAARC is taking substantial steps to mitigate climate change impacts and address current food insecurity regionally through its various declarations, statements, and commissions. However, SAARC falls short on its active role as the main organization to ensure adaptive capacities for South Asian nations; instead, bilateral initiatives between South Asian nations and external international partners are more vibrant, which could be symptomatic of the weak infrastructure and financial and technical capacities of the region. Some of the partnerships are the Cereal Systems Initiatives for South Asia (CSISA) with USAID and the Bill and Melinda Gates Foundation, with the main goal being to sustainably improve cereal productivity, food security, and the income of farmers in South Asia. CSISA claims to "increase the adoption of various resource-conserving and climate-resilient technologies, and improve farmers' access to market information and enterprise development" and "works in synergy with regional and national efforts, collaborating with myriad public, civil society, and private-sector partners." CSISA supports women farmers by "improving their access and exposure to modern and improved technological innovations, knowledge and entrepreneurial skills" [38]. The US also provides agricultural assistance to Afghanistan and Pakistan under the "Food for Progress Programme" [39]. The principal US agency USAID has numerous projects for agriculture in both countries. In Afghanistan, US assistance focuses on capacity-building by creating jobs, income, and productivity, which in turn enhances food security. There are currently numerous multilateral initiatives in place under international organizations such as the United Nations (UN), the Food and Agriculture Organization of the UN (FAO), the World Bank (WB), and the Global Environment Facility (GEF). These international organizations coordinate climate change adaptation efforts, through networks between governments, non-governmental organizations, local organizations, and companies, with the goal of reducing scenarios where food insecurity is a problem. These international organizations are the source of billions of US dollars of financial support to many projects that have been undertaken to date.

South Asia is a beneficiary of many of these funds and programs. Some noteworthy contributions are by the $\mathrm{FAO}$ and $\mathrm{WB}$, which have been directly involved in development efforts. The FAO focuses on developing nations, where it disseminates information about agricultural practices. The FAO has implemented programs related to disaster management and preparedness in Bangladesh and Nepal; capacities for climate change threat mitigation in Nepal; and gender-sensitive strategies for adaptation to climate change and assessment of food security concerns in the overall SAARC region. Similarly, the WB has devised packages and interventions to reduce climate change impacts in the region by introducing better irrigation practices and management of water resources and forecasting natural disasters. These projects and multilateral cooperation have been another source of aid that could help the South Asian region cushion climate change impacts on food security [42].

While the SAARC has openly acknowledged regional threats, there has been little action undertaken to actively address future regional needs, despite SAARC's detailed plans, statements, and declarations, such as the Dhaka Declaration and SAARC Action Plan on Climate Change, the Delhi Statement 
on Cooperation in Environment, and the Thimphu Statement on Climate Change. Multilateral aid partners have developed ways to enhance food security internally and initiated cooperation between governments for better food security governance by providing financial aid to establish an agricultural sector. Furthermore, the CSISA also helps vulnerable populations like women farmers to gain agricultural skills and knowledge. SAARC is heavily reliant on international partners for food security and as a regional organization have yet to take on an active role in regulating or enhancing regional cooperation.

\section{Political Passivity and Divisions}

It may seem unjustified to claim that ASEAN, PIF, and SAARC have been politically passive in terms of addressing climate change and food security, given the various policies and frameworks that exist. Declarations stating the seriousness of climate change were eagerly adopted across ASEAN, PIF, and SAARC. However, these declarations and the assortment of agendas such as AIFS, SPA-FS, the PIF SPREP programs, the PIF Framework for Action and even SAARC's Thimbu agenda have failed to address the crux of the issue. By and large, regional organizations have failed to capitalize on the opportunity that their larger political voice provides to actively address global actors in efforts to slow down or reverse the impacts of climate change in their regions. On the question of climate change food security, we can discern the following response (Table 7) from the three regional organizations under study in terms of their planning, implementation, cooperation, legal obligation, and international contribution.

Table 7. Overview of findings.

\begin{tabular}{llll}
\hline & ASEAN & PIF & SAARC \\
\hline Planning & Extensive & Inclusive & Encompassing \\
Implementation & Potential & Nascent & Inactive \\
Cooperation & Performative & Engaging & Lacking \\
Legal obligation & None & Uncertain & Little to none \\
International contribution & Minimal & Minimal & Nominal \\
\hline
\end{tabular}

ASEAN, PIF, and SAARC have been passive and largely reactive to the global climate change agenda. ASEAN, PIF and SAARC are well-positioned to actively engage with the rest of the world and have a tremendous impetus to do so as populations that reside in these regions are particularly vulnerable to climate change and threats to food security. On a positive note, PIF has shown some examples of how smaller communities can contribute to broadening international knowledge and best practices to effectively deal with future threats. An example is the Pilot Programme for Climate Resilience, which aims to demonstrate methods for subsuming climate risk and resilience under core development planning, without sacrificing the consistent pursuit of development [41]. Other programs that involve PIF and its member nations revolve around the examination of food security and climate change across the Pacific Islands, which will aid future policies by utilizing climate models and data for targeted strategies. To summarize, the programs undertaken thus far foster a multidisciplinary approach by drawing on technical and scientific experts and disseminating best practices and strategies to boost national development sustainability related to adaptive capacities for climate change and food security. Programs for PICTs engage with climate change by information-gathering and developing innovative adaptive mechanisms to mitigate the threats they face. By improving the region's knowledge about climate change, the region will be able to develop Action Plans to communicate between stakeholders, thereby budgeting for and implementing institutional capacity to address regional climate change variability and vulnerability [40]. While PIF may be progressive in its attempts, much of the cooperation does not involve the region but rather forms of bilateral and multilateral cooperation.

ASEAN, however, has a wide range of scope that addresses pertinent environmental issues, from land and agricultural resources to coastal and marine environments. ASEAN does not overlook the 
impacts of the physical environment on the social and economic stability of the region, and also insists that sustainable development must be attained in conjunction with national development goals. ASEAN has been forward-looking, addressing regional food security with external partnerships such as APTERR and AFSIS while at the same time taking long-term measures to establish food trade development, information systems, and agri-innovation under the AIFS framework. ASEAN as a regional body has indeed been active in promoting formal avenues for collaboration between its member states to enhance regional strategies for knowledge and capacity development to address climate change and food security issues. Hence, in terms of planning, ASEAN has a clear foundational strategy for collaboration and avenues to facilitate discussion of mitigation and adaptation measures.

However, there are two main caveats concerning the extensive initiatives laid out by ASEAN. First, ASEAN emphasizes that member nations must respect the 1976 Treaty of Amity and Cooperation (TAC), which endorses non-interference in domestic affairs. This notion is termed the "ASEAN Way." This policy has led to the restriction of regional cooperation and adaptation, due to the avoidance of any action that might be interpreted as an infringement of national sovereignty. The non-legally binding agreements are more disadvantageous for ASEAN because climate change impacts and methods to mitigate the effects are neither tangible nor concrete at this moment. Due to the underlying consensus on respecting national sovereignty, cross-boundary programs may be unnecessarily held back. As evidence of the lack of legality of ASEAN agreements, we must look at the extent of cooperation ASEAN elicits between its member nations. We can do so by examining ASEAN's actions to prevent annual transboundary haze originating from Indonesia. The haze is brought about by the slash and burn techniques of commercial and private landowners. The extensive deforestation due to burning causes a massive haze to settle over Indonesia's neighbors, Singapore and Malaysia. However, despite the seemingly concrete actions of the 1997 Regional Haze Action Plan and the following 2003 ASEAN Agreement on Transboundary Haze Pollution, this framework is non-legally binding, and thus the clashes between Indonesia and those nations due to the haze problem affected were not resolved. Indonesia claimed that the haze problem was a domestic issue and other ASEAN member nations should not interfere. This clash is indicative of the weak executive and legislative powers of ASEAN as an association for coordinating and implementing programs across its member nations. Second, ASEAN nations continue to pursue environment-related issues only if doing so does not affect the pursuit of their national developmental agendas. Both matters highlight the extent of cooperation between member nations, which has found minimal headway in terms of addressing long-term structural changes and cooperation.

Without full commitment to addressing climate change impacts, many nations today have made climate change issues secondary to their development agendas. Many nations thus fail to cooperate on vital issues, which creates a mutual lack of trust. This is particularly clear with SAARC, where there is constant mistrust between its member nations. SAARC has been highly outspoken in its attempts to work on regional initiatives and cooperate on matters laid out by SAARC initiatives. However, SAARC regional cooperation and lack of commitment can be exemplified by the July to August floods that afflicted Pakistan [42]. The floods impacted Pakistan tremendously, damaging infrastructure and affecting millions of people. While there was a pledge of US\$32 million, there were no additional supports from SAARC member nations to Pakistan during this time of crisis. The super-floods that hit Pakistan came only months after the Silver Jubilee SAARC Summit, which had the climate as its main theme [42,43]. In addition, the South Asian socio-political scene has been hampered by conflicts due to its plural socio-cultural background. Security issues include violence, terrorism, ethnic conflicts (in Kashmir, among Sri Lanka's Tamil and Sinhala populations, among Karachi's Mohajirs, and between Sind and Baluchistan), the instability of Nepal's Communist Party, and political unrest in Bangladesh. Many SAARC nations face internal struggles that are an impediment to regional cooperation. In addition, both Afghanistan and Pakistan face external armed confrontations with fundamentalist forces and US-NATO interference, severely undermining political security in the South Asian region. Bilateral disputes between India and other members of SAARC member states have been an impediment to 
SAARC initiatives. India's posturing as a regional power and distrust of Pakistan create cross-border tensions which result in proxy conflicts against India, sowing doubts over India's regional objectives among its SAARC neighbors. Although SAARC has weathered many events and conflicts, there has been little progress in furthering regional goals and objectives [42,44]. The relevance of SAARC as an intermediary platform has been brought into question by its lack of relevance as a regional governing body. Hence, SAARC's initiatives and attempts to address regional issues have been largely overshadowed by its failures $[45,46]$.

\section{Conclusions: Towards Polarizing Vulnerability}

In the regions we have examined, many populations are already facing poverty, and the situation will become worse with climate change. Furthermore, as previously noted, many of the initiatives undertaken have given minimal consideration to marginalized populations. The failure to consider the marginalized and the emphasis on development will only expand inequality gaps. Regional meetings have become a platform for mere reiteration of the dominant discourse on climate change and food security. Adopting dominant discourses may not be detrimental, but it can be problematic if the regions focused on are most likely to be disproportionately affected by climate change, which will require proactive engagement both within each region and with the global community. Climate change impacts disproportionately affect certain regions relative to the carbon emissions they produce, and those who are least capable of adaptation are the poorer regions and communities.

Attaining food security for these regions will be an enormous task for the coming years. Safeguards and preventive measures against these challenges have a hard time justifying the costs incurred, especially for the unknown impacts of climate change. However, the pursuit of economic growth seems to be the motivating factor for national and regional improvement, as it is necessary to alleviate poverty and food insecurity. Nonetheless, economic growth is not sufficient to tackle climate change; on the contrary, it may accelerate unsustainable development, resulting in worsening climate change. Agricultural, aquaculture, and marine production for the region must be raised to attain food security despite the multitude of challenges, which include the impacts of climate change. A global challenge requires a collective global effort to collaborate on and promote strategies to mitigate climate change threats. Due to the nature of the demands on agriculture, aquaculture, and marine fisheries, there should be a set of responses to address the specific needs of each industry, and protective and regulatory policies to ensure that food production is in line with the region's needs.

Likewise, the notion of vulnerability is also pertinent, as global inequalities lead to polarizing trajectories of food security vulnerability between "climate change haves" and "climate change have-nots." Those at the better end of climate change can buffer themselves from food security threats from market price fluctuations and position themselves at the receiving end of the global commodity chain. This resource competition will ultimately displace much of the threats from climate change and food security onto those who have very little means to adapt. Social equity is one important dimension for sustainable development, as it can help eliminate poverty, improve health and education, and aid good governance. The neoliberalism so fervently championed by many First World governments and international institutions will only benefit some at the expense of others. Regional organizations should, therefore, understand their position within the global economy and strive towards regional cooperation and self-determination. Blind pursuit of economic development may not be an option or prerogative for all nations or regions. However, fragmentation within regions is still related to competing for power interests and rooted in the notion of development. We can see this issue clearly from ASEAN and SAARC, where the drive for national economic development still supersedes preventive measures against future threats. Failure to move beyond our current conceptions about development may be the single biggest obstacle to addressing climate change.

Global climate change and food security trends can be optimally managed by regional organizations, but their potential has not been realized. Because of the global nature of both issues, the multi-level, multi-sector approaches highlighted by many regional organizations should go 
beyond the region and extend towards pro-active engagement with the global community. However, such engagement can be concurrent with immediate policy action within reach region to regulate and manage food security and production. There is a vital need to re-evaluate regional and national priorities to enhance sustainable development for the future. The constant problematization of current trajectories of climate change and food security may lead us to reconsider and re-evaluate policies in search of improvements and solutions. Without a doubt, climate change and food security will continue to plague us over the next few decades as we continue to prioritize short-term development over long-term sustainability. Declarations and frameworks that do not tackle the root of our problems today will not solve climate change and food security threats. Progressive steps can be taken towards cooperation, especially at the regional level. First, regional cooperation for genuine policies and frameworks for tackling climate change and food security should supersede developmental trajectories. Second, regional organizations ought to move beyond mitigation and prevention to proactively engage global partners in connection with climate change issues, while strengthening internal food production and regulating regional markets. Adaptive action should not require a "degree of confidence" about the impacts of climate change before coping mechanisms can be set in place and the necessary investments made. Adaptive action must be taken to mitigate threats and modified accordingly as new developments unfold. This dual approach could pave the way towards progress, as we continually revise policies and remove impediments to greater commitment and an equitable future.

Author Contributions: The paper was conceptualized together by both authors. E.K. wrote the first draft, and then both worked together to finalize the manuscript. Both authors agree with this final version, and claim equal authorship. All authors have read and agreed to the published version of the manuscript.

Funding: The paper was funded by a Tier-1 grant [Grant No. RG 67/18 (NS)], supported by the Ministry of Education, Singapore.

Acknowledgments: The authors thank participants during the Sustainability and Development Conference, University of Michigan, 9-11 November 2018 for their comments and suggestions on the earlier draft of this paper. They also thank the reviewers of this paper for their thoughtful reviews.

Conflicts of Interest: The authors declare no conflict of interest.

\section{References}

1. Andrić, I.; Koc, M.; Al-Ghamdi, S.G. A review of climate change implications for built environment: Impacts, mitigation measures and associated challenges in developed and developing countries. J. Clean. Prod. 2019, 211, 83-102. [CrossRef]

2. Ciplet, D.; Roberts, J.T. Climate change and the transition to neoliberal environmental governance. Glob. Environ. Chang. 2017, 46, 148-156. [CrossRef]

3. Islam, M.S. Development, Power and the Environment: Neoliberal Paradox in the Age of Vulnerability; Routledge: New York, NY, USA, 2013; pp. 139-154.

4. Leisner, C.P. Review: Climate change impacts on food security-Focus on perennial cropping systems and nutritional value. Plant Sci. 2020. [CrossRef]

5. Jiricka-Pürrer, A.; Wachter, T. Coping with climate change related conflicts-The first framework to identify and tackle these emerging topics. Environ. Impact Assess. Rev. 2019, 79, 106308. [CrossRef]

6. Sultana, P.; Thompson, P.M. Adaptation or conflict? Responses to climate change in water management in Bangladesh. Environ. Sci. Policy 2017, 78, 149-156. [CrossRef]

7. Roberts, J.T. Multipolarity and the new world (dis)order: US hegemonic decline and the fragmentation of the global climate regime. Glob. Environ. Chang. 2011, 21, 776-784. [CrossRef]

8. Thorpe, A.; Figge, F. Climate change and globalisation as 'Double Exposure': Implications for policy development. Environ. Sci. Policy 2018, 90, 54-64. [CrossRef]

9. Nagoda, S.; Nightingale, A.J. Participation and Power in Climate Change Adaptation Policies: Vulnerability in Food Security Programs in Nepal. World Dev. 2017, 100, 85-93. [CrossRef]

10. Madumere, N. Public enlightenment and participation-A major contribution in mitigating climate change. Int. J. Sustain. Built Environ. 2017, 6, 9-15. [CrossRef]

11. McMichael, P. Development and Social Change: A Global Perspective; Sage: Washington, DC, USA, 2012. 
12. Expert Group Meeting on the Impact of Climate Change on ASEAN Food Security 2013. Available online: https://www.rsis.edu.sg/wpcontent/uploads/2014/07/ER130607_Impact_of_Climate_Change_on_ ASEAN.pdf (accessed on 25 September 2017).

13. Islam, M.S.; De Jesus, I.C. Regional Initiatives on Food Security. In The Challenge of Food Security: International Policy and Regulatory Frameworks, 1st ed.; Rayfuse, R., Weisfelt, N., Eds.; Edward Elgar Publishing Limited: Northampton, MA, USA, 2012; pp. 255-274.

14. Food Security: Concepts and Measurements. Available online: http://www.fao.org/WFS/ (accessed on 25 September 2017).

15. Food Security. Available online: http://www.fao.org/forestry/13128-0e6f36f27e0091055bec28ebe830f46b3.pdf (accessed on 25 September 2017).

16. Islam, M.S.; Wong, A. Climate change and food (in) security: A critical intersection. Environments 2017, 4, 38. [CrossRef]

17. Kais, S.M.; Islam, M.S. Impacts of and Resilience to Climate Change at the Bottom of the Shrimp Commodity Chain in Bangladesh: A Preliminary Investigation. Aquaculture 2018, 493, 406-415. [CrossRef]

18. IPCC Forth Assessment Report: Climate Change 2007. Available online: https://www.ipcc.ch/publications (accessed on 25 September 2017).

19. Chand, R. SAARC Agricultural Vision 2020. Agric. Econ. Res. Rev. 2010, 23, 197-208.

20. Mahlstein, I.; Portmann, R.W.; Daniel, J.S.; Solomon, S.; Knutti, R. Perceptible Changes in Regional Precipitation in a Future Climate. Geophys. Res. Lett. 2012, 39, L05701. [CrossRef]

21. Shiu, C.J.; Lui, S.C.; Fu, C.; Dai, A.; Sun, Y. How Much Do Precipitation Extremes Change in a Warming Climate? Geophys. Res. Lett. 2012, 39, L17707. [CrossRef]

22. Williamson, S.E.; Middleton, J. Climatic Seasonality, Resource Bottlenecks, and Abundance of Rainforest Birds: Implications for Global Climate Change. Divers. Distrib. 2008, 14, 69-77. [CrossRef]

23. Siepielski, A.M.; DiBattista, J.D.; Carlson, S.M. It's About Time: The Temporal Dynamics of Phenotypic Selection in the Wild. Ecol. Lett. 2009, 12, 1261-1276. [CrossRef] [PubMed]

24. Reynolds, M.P. Climate Change and Crop Production; CABI: Oxford, UK, 2010.

25. FAO (Food and Agriculture Organization of the United Nations). World Summit on Food Security: Declaration of the World Summit on Food Security. Available online: http://www.fao.org/fileadmin/templates/wsfs/ Summit/Docs/Final_Declaration/WSFS09_Declaration.pdf (accessed on 25 September 2017).

26. Climate Change and Food Security in the Pacific Island Countries. Available online: http://www.fao.org/ docrep/011/i0530e/i0530e00.HTM (accessed on 25 September 2017).

27. Lal, M. Climate Change in Small Island Developing Countries of the South Pacific. Fijian Stud. 2004, 2, 15-31.

28. Desker, B.; Caballero-Anthony, M.; Teng, P. Thoughts/Issues on ASEAN Food Security: Towards a More Comprehensive Framework; ERIA Discussion Paper Series; ERIA: Senayan Jakarta Pusat, Indonesia, 2013; pp. 1-43.

29. ASEAN Sustainable Agrifood Systems ASEAN Integrated Food Security (AIFS) Framework and Strategic Plan of Action on Food Secuity in the ASEAN Region (SPA_FS 2015-2020). Available online: http: //asean-agrifood.org/?wpfb_dl=58 (accessed on 9 October 2017).

30. ASEAN Cooperation on Environment ASEAN Cooperation on Climate Change. Available online: http: //environment.asean.org/asean-working-group-on-climate-change/ (accessed on 25 September 2017).

31. ASEAN Multi Sectoral Framework on Climate Change: Agriculture, Fisheries and Forestry towards Food Security (AFCC). Available online: http://www.fao.org/fileadmin/templates/rap/files/meetings/2011/ 110329asean.pdf (accessed on 25 September 2017).

32. ASEAN Integrated Food Security (AIFS) Framework and Strategic Plan of Action on Food Security in the ASEAN Region (SPA-FS). Available online: https://www.asean.org/storage/images/archive/22338.pdf (accessed on 8 December 2017).

33. 12th ASEAN Ministerial Meeting ASEAN Action Plan on Joint Response to Climate Change. Available online: http://environment.asean.org/wp-content/uploads/2015/06/ANNEX-8-Lead-Countries-for-ASEANAction-Plan-on-Joint-Response-to-Climate-Change-27-March-2013.pdf (accessed on 9 October 2017).

34. Towards a Food Secure Pacific; Framework for Action on Food Security in the Pacific 2011-2015. Available online: http://lrd.spc.int/pubs/doc_download/1055-towards-a-food-secure-pacific-2011-2015-. (accessed on 9 October 2017). 
35. Progress on Food Security in the Pacific. Available online: http://www.wpro.who.int/southpacific/pic meeting/2011/documents/PIC9_10_progress_on_food_security.pdf (accessed on 9 October 2017).

36. Thimphu Statement on Climate Change. Available online: http://www.saarcsec.org/userfiles/ ThimphuStatementonClimateChange-29April2010.pdf (accessed on 20 October 2015).

37. A Guide to the SAARC Food Bank. Available online: http://saarc-sec.org/assets/responsive_filemanager/ source/Files\%20for\%20Areas\%20of\%20Cooperation/ARD/06.a_A\%20Guide\%20to\%20the\%20SAARC\% 20Food\%20Bank.pdf (accessed on 9 October 2017).

38. CSISA (Cereal Systems Initiative for South Asia) Overview. Available online: http://csisa.org/about-csisa/ overview/ (accessed on 9 October 2017).

39. Mittal, S. Regional and International Cooperation. In Climate Change and Food Security in South. Asia, 2nd ed.; Chatterjee, B., Khadka, M., Eds.; CUTS International: Jaipur, India, 2011; pp. 87-106.

40. Pacific Islands Framework for Action on Climate Change 2009-2015. Available online: http://www.sprep. org/climate_change/pycc/documents/PIFACC.pdf (accessed on 9 October 2017).

41. Pacific Climate Change Portal. Available online: http://projects.pacificclimatechange.net/ (accessed on 9 October 2017).

42. Sharma, S. Existential Threat to Human Security in South Asia and Regional Response: A Case Study of Climate Change and SAARC Initiatives; University of Delhi: Delhi, India, 2011.

43. What We Do. Available online: http://www.sacep.org/?page_id=781 (accessed on 9 October 2017).

44. Area of Cooperation (Environment). Available online: http://globalsummitryproject.com.s197331. gridserver.com/archive/saarc/saarc-sec.org/areaofcooperation/cat-detail1a12.html?cat_id=54 (accessed on 9 October 2017).

45. Pacific Leaders' Call to Action on Climate Change. Annex A to the 2009 Forum Leaders' Communique. Available online: http://www.forumsec.org/resources/uploads/attachments/documents/Pacific\%20Leaders' \%20Call\%20to\%20Action\%20on\%20Climate\%20Change\%202009.pdf (accessed on 25 September 2017).

46. Agreement on Establishing the SAARC Food Security Reserve. Available online: http://www.ifrc.org/Docs/ idrl/N646EN.pdf (accessed on 9 October 2017).

(C) 2020 by the authors. Licensee MDPI, Basel, Switzerland. This article is an open access article distributed under the terms and conditions of the Creative Commons Attribution (CC BY) license (http://creativecommons.org/licenses/by/4.0/). 